\title{
Community Empowerment Through Independent Family Health Evaluation (IFHE)-based Healthy Villages
}

\author{
Diyan Indriyani ${ }^{1,}$ Asmuji $^{1,}$ Triawan Adi Cahyanto ${ }^{2}$ Astrid Maharani ${ }^{3,}$ Sri \\ Wahyuni $\mathrm{A}^{1}$
}

\begin{abstract}
${ }^{1}$ Faculty of Health Sciences, University of Muhammadiyah Jember, Maternity Nursing Departement, Indonesia
${ }^{2}$ Faculty of Engineering, University of Muhammadiyah Jember, Informatics Engineering department, Indonesia ${ }^{3}$ Faculty of Economics and Business, University of Muhammadiyah Jember, Finacial Accounting Departement, Indonesia

*Corresponding author email: diyanindriyani@unmuhjember.ac.id
\end{abstract}

\begin{abstract}
Partners are Tutul Village, Balung District, Jember Regency. The objectives of this study are 1) identification of the community paradigm in the health sector, especially independence in recognizing changes in health status, 2) identification of entrepreneurship in the health sector that supports the family economy. As a solution for strengthening the Healthy Village program based on Independent Family Health Evaluation (IFHE).. Method: The activity takes for about 8 months. The approach method has several stages, namely: forming a task force team, mapping the family health area, strengthening the competence of the task force team, preparing the IFHE health identification format, testing the IFHE format and assisting families in identifying family health status independently. The results that were obtained were the increasing of knowledge and skills toward the health themes on the task force team, the family was able to identify family health status using the IFHE format and the increasing of the knowledge, skills, and family health behaviour. The conclusion is the improving public health behavior with the support of the Task Force Team and the entire community can make the IFHE-based Healthy Village
\end{abstract}

Keywords: Community, Family Health Evaluation, Healthy Villages

\section{INTRODUCTION}

Family health is important to build public health. The government has stimulated one of the development models of village community empowerment by creating Healthy Villages independently to synergize village development and improve the health as a potential quality of village communities. A village with a healthy category of achievement indicators includes increasing the capacity of "PKK" and "Posyandu" cadres to support the realization of family welfare.

Community participation in struggling to achieve health development goals needs to be pushed together in order to create a community life order with the paradigm of "Healthy Village" which is expected to have the direct implications for improving the health status and welfare of rural communities [1]. According to [2] that the concept of a healthy village is a movement to create a village with a community condition that has the knowledge about health, is able to adopt a clean and healthy lifestyle both physically and spiritually, creates a healthy, clean, tidy environment, is able to utilize the natural resources that exists for the survival of both oneself and others and the healthy which is in the sense of economically independent.
Reciprocally with the Government's policy, it is obliged in stages to encourage community participation in struggling to improve the health so that people live healthy by determining the priorities for the use of Village Funds for development and empowerment of rural communities, especially in the health sector through active Community Based Health Efforts "(UKBM)". The goal is for the community to be able to solve health problems independently and to adopt a clean and healthy lifestyle "(PHBS)" with a healthy and conducive environment [3].

Tutul Village is a village with part of its residents classified as poor families, the majority of the population has 9 years of education, farmers and the productive age is $>52.7 \%$, there are many health problems such as late handling, it is one of 132 productive villages and becomes a digital unit village in 2016 [4]. However, Tutul Village is a village that has the potential to be a healthy village because it has a regular rhythm of life, a great relationship between the Village Head and the community, a maintained custom, a running community self-help, there is an active "Posyandu" in every hamlet, has a clear vision, complete village institutions. , and Jember Regency has supported the 
Healthy Indonesian Community Movement in 2018 [5].

Based on the interview results, surveys and data identifications, Tutul Village has several problems, namely 1) the community paradigm in the health sector is not optimal, especially the independence in recognizing changes in health status, 2) the absence of entrepreneurship in the health sector that supports

\section{METHOD}

\subsection{Preparation Stage}

The activity was conducted in Tutul Village, Balung District, Jember Regency. It began with administering the administration / licensing to the Jember Regency Political and National Unity Agency, the Jember Regency health office, Karangduren Health Center, Balung District and Tutul Village to prepare the planned activities.

\subsection{Implementation Stage}

a. Coordinating the Implementation Team

b. Coordinating with Implementing Partners

c. Establishing an IFHE-based Healthy Village Task Implementation Team (SATGAS) in Tutul Village

d. Coordinating the University of Muhammadiyah Jember Implementation Team with the IFHEbased Healthy Village Task Implementation Team

e. Mapping health areas and identifying preliminary data on families in Tutul Village, the sample was taken $10 \%$ (300 heads of households) of the total heads of families ("KK") in Tutul Village.

f. Disseminating the results of the mapping of family health areas

g. Conducting the training on the Task Team in the form of providing healthy information I, II and III.

h. Conducting a Workshop on the preparation of the Family Health Identification Format using the IFHE-based Healthy Village approach (Manual Form IFHE).

i. Testing the IFHE Form Manual on Families in Tutul Village, as well as revising the IFHE form manual

j. Guiding on family health identification applications to using the IFHE manual form.

\subsection{Evaluation Stage}

a. The evaluation of activity processes Evaluating every activity that had been conducted

b. The evaluation of the activity results the family economy. This requires a massive solution in the form of a holistic approach to strengthening the IFHE-based Healthy Village program. The expected outcome target in this activity is that the families in Tutul Village are able to independently identify family health status using the IFHE format, improve the knowledge, skills and family ownership and the optimal health behavior. Evaluating the results by knowing the level of goal achievement includes: understanding of the IFHEbased Healthy Village Task Force Team on training I, II and III with the topic of community health, optimizing the nutrition to prevent the stunting, recognizing the cardiovascular disorders, high risk of perinatal periods (antenatal, intranatal and postnatal ), childbirth care, adolescent reproductive health, increasing adolescent activities as an effort to prevent drugs, recognizing chronic disease and preventing recurrence, synergizing health services in building a Healthy Village, family planning, recognizing diseases of infants and toddlers, stimulating growth and development of infants and toddlers and empowering community in creating a healthy village.

c. The evaluation of activity impact

Evaluating the impact of activities to see the effect of activities seen from the ability of families to identify the health through the IFHE manual form as well as the changes of knowledge and health behavior.

\subsection{Research Instruments}

In this study, the intervention carried out by researchers was in the form of education or provision of health information using module media, the IFHE format. Furthermore, in measuring the understanding ability of the task implementation team, "Posyandu" representatives and community association representatives, using instruments a) general data questionnaire and family health status, b) training questionnaires I, II and III. The questionnaire has been tested for validity and reliability on 30 respondents with $r$ table value of 0.3550 at alpha $5 \%(0.05)$. The test results on the first training questionnaire are valid and the Cronbach's Alpha value is 0.807 , the second training instrument is valid and the Cronbach's alpha value is 0.826 , the third training instrument is valid and the Cronbach's Alpha value is 0.813 .

\subsection{Data Analysis}

In this study, the data analysis used was univariate analysis (frequency distribution, numerical data: minimum, maximum, mean, standard deviation), 
and bivariate analysis using Paired T-Test with an alpha value of $5 \%(0.05)$.

\section{THE RESULT AND DISCUSSION}

The results were obtained in this activity including the formation of an IFHE-based Healthy Village Task Team, mapping the family health areas, providing the health information I, II and III, as well as application processes and guiding the family in identifying family health using the IFHE manual form, changing the knowledge and behavior of health. This is illustrated in the description below:

3.1 Mapping the Family Health Areas on the initial assessment that was carried out on 17-23 June 2020.

TABLE 1 Mapping of General Data and Family Health Status in Communities in Tutul Village, Balung District, Jember Regency in 2020. $\mathrm{n}=300$

\begin{tabular}{|c|c|c|c|c|}
\hline \multirow[b]{2}{*}{$\mathrm{No}$} & & & & \\
\hline & variable & category & total & percentage \\
\hline \multirow[t]{17}{*}{1} & \multirow{17}{*}{$\begin{array}{l}\text { The head of family } \\
\text { identity }\end{array}$} & Total & 300 & 100 \\
\hline & & The head of family age: & & \\
\hline & & $<20$ years & 4 & 1,3 \\
\hline & & $20-40$ years & 206 & 68,7 \\
\hline & & $41-50$ years & 74 & 24,7 \\
\hline & & $>50$ years & 16 & 5,3 \\
\hline & & The head of family Education: & & \\
\hline & & uneducated & 2 & 0,7 \\
\hline & & Elementary School -junior high school & 180 & 60 \\
\hline & & Senior high school & 100 & 33,3 \\
\hline & & college & 18 & 6 \\
\hline & & The job of family head: & & \\
\hline & & Soldier-Police & 1 & 0,3 \\
\hline & & Civil servants & 4 & 1,3 \\
\hline & & Farmer & 87 & 29 \\
\hline & & Merchant & 24 & 8 \\
\hline & & Private employees & 184 & 61,4 \\
\hline \multirow[t]{22}{*}{2} & \multirow{22}{*}{$\begin{array}{l}\text { Pregnant Women } \\
\text { Group }\end{array}$} & total & 24 & 100 \\
\hline & & age: & & \\
\hline & & $<20$ years & 3 & 12,5 \\
\hline & & 20-35 years & 21 & 87,5 \\
\hline & & $>35$ years & 0 & 0 \\
\hline & & Number of pregnancies: & & \\
\hline & & The first child & 7 & 29,2 \\
\hline & & Second child & 7 & 29,2 \\
\hline & & The third child & 9 & 37,5 \\
\hline & & Child > 3 & 1 & 4,1 \\
\hline & & Pregnancy test: & & \\
\hline & & Doing Antenatal Care & 22 & 91,7 \\
\hline & & Undoing Antenatal Care & 2 & 8,3 \\
\hline & & Tetanus Toxoid Immunization: & & \\
\hline & & Undoing tetanus toxoid Immunization & 14 & 58,3 \\
\hline & & Doing tetanus toxoid Immunization & 10 & 41,7 \\
\hline & & Complaints During Pregnancy: & & \\
\hline & & Low blood pressure & 4 & 16,7 \\
\hline & & Malnutrition & 1 & 4,1 \\
\hline & & Swollen foot & 3 & 12,5 \\
\hline & & other & 4 & 16,7 \\
\hline & & No complaints & 12 & 50 \\
\hline
\end{tabular}




\begin{tabular}{|c|c|c|c|c|}
\hline No & variable & category & total & percentage \\
\hline \multirow[t]{16}{*}{3} & \multirow{16}{*}{$\begin{array}{l}\text { Breastfeeding } \\
\text { Mothers Group }\end{array}$} & total & 77 & 100 \\
\hline & & Breastfeeding: & & \\
\hline & & Breastfeeding & 69 & 89,6 \\
\hline & & Not breastfeeding & 8 & 10,4 \\
\hline & & Complaints about Breastfeeding: & & \\
\hline & & Breastfeeding is not smooth & 15 & 19,5 \\
\hline & & Swollen breasts & 1 & 1,3 \\
\hline & & The baby does not want to breastfeed & 1 & 1,3 \\
\hline & & other & 13 & 16,9 \\
\hline & & No complaints & 47 & 61 \\
\hline & & Personal Hygiene Health Education: & & \\
\hline & & Getting health education: & 71 & 92,2 \\
\hline & & Not getting health education & 6 & 7,8 \\
\hline & & $\begin{array}{l}\text { Breastfeeding Mothers Nutrition Health } \\
\text { Education: }\end{array}$ & & \\
\hline & & Getting health education & 70 & 90,9 \\
\hline & & Not getting health education & 7 & 9,1 \\
\hline \multirow[t]{16}{*}{4} & \multirow{16}{*}{$\begin{array}{l}\text { Infant and Toddler } \\
\text { Group }\end{array}$} & Total of infant & 21 & 9,1 \\
\hline & & Total of Toddlers & 211 & 90,9 \\
\hline & & Exclusive breastfed babies & & \\
\hline & & Yes & 180 & 85,3 \\
\hline & & No & 21 & 10 \\
\hline & & No breastmilk & 10 & 4,7 \\
\hline & & Immunization: & & \\
\hline & & Immunization & 205 & 97,1 \\
\hline & & Not getting Immunization yet & 6 & 2,9 \\
\hline & & Toddler Nutritional Status: & & \\
\hline & & Below the Red Line & 2 & 0,9 \\
\hline & & Bottom-top yellow area & 58 & 27,5 \\
\hline & & Bottom-top light green area & 80 & 37,9 \\
\hline & & Dark green area & 71 & 33,7 \\
\hline & & Dalan's sick for the last 1 year & & \\
\hline & & Complaints Now & & \\
\hline \multirow[t]{11}{*}{5} & \multirow[t]{11}{*}{ School-Age Group } & Total & 126 & 100 \\
\hline & & Complaints or illnesses: & & \\
\hline & & Malnutrition & 2 & 1,6 \\
\hline & & Cough-cold-shortness of breath & 6 & 4,8 \\
\hline & & Itchy & 5 & 3,9 \\
\hline & & other & 19 & 15,1 \\
\hline & & Never being sick & 94 & 74,6 \\
\hline & & Sick in the last 1 year: & & \\
\hline & & Never & 48 & 38,1 \\
\hline & & Being sick 1-2 times & 74 & 58,7 \\
\hline & & Being sick 2-4 times & 4 & 3,2 \\
\hline \multirow[t]{7}{*}{6} & \multirow[t]{7}{*}{ Youth Group } & Total & 76 & 100 \\
\hline & & Bad Behaviour: & & \\
\hline & & Smoking & 11 & $14,, 5$ \\
\hline & & Nothing & 65 & 85,5 \\
\hline & & Good Beahviour: & & \\
\hline & & Youth organization & 5 & 6,6 \\
\hline & & Mosque Youth & 6 & 7,9 \\
\hline
\end{tabular}




\begin{tabular}{|c|c|c|c|c|}
\hline No & variable & category & total & percentage \\
\hline & & PIKR & 2 & 2,6 \\
\hline & & other & 17 & 22,4 \\
\hline & & No activity & 46 & 60,5 \\
\hline & & Current illness or complaints: & & \\
\hline & & More nutrition & 1 & 1,3 \\
\hline & & Malnutrition & 4 & 5,3 \\
\hline & & Cough-cold-shortness of breath & 1 & 1,3 \\
\hline & & Itchy & 1 & 1,3 \\
\hline & & Other & 1 & 1,3 \\
\hline & & Not being sick & 68 & 89,5 \\
\hline \multirow[t]{8}{*}{7} & \multirow[t]{8}{*}{ Adult Group } & The disease being suffered: & 107 & 100 \\
\hline & & Asthma & 10 & 9,4 \\
\hline & & Heart disease & 1 & 0,9 \\
\hline & & Diabetes & 2 & 1,9 \\
\hline & & Hypertension & 1 & 0,9 \\
\hline & & TBC & 1 & 0,9 \\
\hline & & Rheumatism & 28 & 26,2 \\
\hline & & Not Being sick & 64 & 59,8 \\
\hline \multirow[t]{18}{*}{8} & \multirow[t]{18}{*}{ Elderly Group } & Total & 52 & 100 \\
\hline & & Current complaints: & & \\
\hline & & Diabetes & 4 & 7,7 \\
\hline & & Asthma & 2 & 3,8 \\
\hline & & Heart disease & 1 & 1,9 \\
\hline & & Hypertension & 2 & 3,8 \\
\hline & & Rheumatism & 13 & 25 \\
\hline & & Other disease & 14 & 26,9 \\
\hline & & No complaints & 16 & 30,9 \\
\hline & & Attending the elderly Posyandu: & & \\
\hline & & Attending & 5 & 9,4 \\
\hline & & Not attending & 47 & 90,3 \\
\hline & & The elderly aerobic: & & \\
\hline & & Joining & 4 & 7,7 \\
\hline & & Not Joining & 48 & 92,3 \\
\hline & & Penkes of Nutrition for the elderly: & & \\
\hline & & joining & 6 & 11,5 \\
\hline & & Not joining & 46 & 88,5 \\
\hline
\end{tabular}

Table 1 shows that the majority of family heads aged $20-40$ years are 206 heads of families $(68.7 \%)$, the majority of pregnant women aged 20-30 years are 21 respondents $(87.5 \%)$, breastfeeding mothers 69 respondents $(89.6 \%)$. and 8 respondents $(10.4 \%)$ did not breastfeed, $180(85.3 \%)$ under five had a history of exclusive breastfeeding, 2 respondents $(1.6 \%)$ had poor nutrition in school-age children, 11 respondents $(14,5 \%))$, the most common disease in the adult group was rheumatism, namely 28 respondents $(26 \%)$, and the elderly who suffered the most from rheumatism were 13 respondents $(25 \%)$.

\subsection{Activities to provide 1st health information to the IfHE-based Healthy Village Task Force team in Tutul Village.}

To improve the competence of the Task Implementation Team, then on June 25, 2020, the provision of $1^{\text {st }}$ health information with the theme of community health, optimization of nutrition in preventing stunting, recognize cardiovascular disorder disease, high risk of perinatal period. Aiming at knowing the effectiveness of providing such information, the Executive Team conducted the measurements in pretest and posttest form. The 
measurement results showed that the activities of $1^{\text {st }}$ providing health information to the IFHE-based Healthy Village Task Force Team, "Posyandu" Representatives and Community association ("RW") representatives were obtained for healthy village support community health materials with a value of P 0.01. Material recognized cardiovascular disorder disease $\mathrm{p}$ value 0.02 , material recognized pregnancy high risk $\mathrm{p}$ value 0.01 and nutrition fulfillment material prevent stuanting incidence in toddlers $p$ value 0.04 . Based on this, it can be said that there is an influence of the $1^{\text {st }}$ providing health information with the knowledge of the IFHE-based Healthy Village Task Force Team, Posyandu Representatives and RW representatives in Tutul Village about the health of healthy village support communities, knowing cardiovascular disorders, high risk pregnancy and nutrition fulfillment preventing stunting events in toddlers.

\subsection{The 2nd activity of providing health information to the IFHE-based Healthy Village Task Team in Tutul Village.}

Through the $2^{\text {nd }}$ activity of providing health information which was held on July 2, 2020 at the IFHE-based "SATGAS" Village Team, "Posyandu" and Community association representatives obtained measurement results on chronic disease material: recurrence prevention and management with a $\mathrm{P}$ Value of 0.02 . Maternal care and complications prevention material $\mathrm{P}$ value 0.01 , adolescent reproductive health material $p$ value 0.05 and material optimizing adolescent activities in preventing drug use with $p$ value 0.04 . Based on this, it can be said that there is an effect of the $2^{\text {nd }}$ providing health information with the knowledge of the IFHE-based Healthy Village "SATGAS" Team, "Posyandu" and Community association representatives in Tutul Village about chronic diseases: recurrence prevention and management, postpartum care and complications prevention, adolescent reproductive health and activity optimization adolescents in preventing of drug use.

\subsection{The activity of the 3rd providing health information to the IFHE-based Healthy Village Task Team in Tutul Village.}

Next, the activity of providing health information III to the "SATGAS" Team, community association representatives and "Posyandu" representatives was carried out on July 9, 2020. Based on the measurement results on the provision of $3^{\text {rd }}$ health information with the theme of health service synergy in optimizing Healthy Villages, the P Value was 0.03 , planning theme family in realizing healthy family planning a $\mathrm{P}$ value 0.00 , the theme of stimulation of growth and development of infants and toddlers obtained $p$ value 0.01 and the theme of recognizing diseases of infants and toddlers obtained $\mathrm{P}$ value of 0.02 . Based on this, it can be concluded that the provision of health information III affects the knowledge of the IFHE-based Healthy Village "SATGAS" Team, Posyandu representatives and community association representatives in Tutul Village about the synergy of health services in optimizing healthy villages, family planning in realizing healthy family planning, stimulating growth and development. babies and toddlers and know the diseases of Infants and Toddlers.

\subsection{Conducting a Workshop on the Formulation of Family Health Identification Format Using the IFHE-Based Healthy Village Approach.}

Identifying the family health in Tutul Village requires media as a measuring tool. Based on this, a workshop was conducted as a scientific activity to compile the format. The activity was held on July 18 , 2020 which was attended by the PPDM implementation team, the SATGAS Team, experts, related institutions and institutions as well as lecturers in the field of community and family. Through this workshop, a family health identification format was formulated using an IFHEbased healthy village approach.

\subsection{Trying out the Family Health Identification Format and Family Assistance}

After the IFHE format was revised, the implementing team and the SATGAS team then tested the format by taking a sample of 50 households on July $28^{\text {th }}-$ August $3^{\text {rd }}, 2020$. Furthermore, the family was given the continuous assistance until the family was able to identify family health through filling out the format to conclude the scoring of family health status. Based on the health information that had been received by the family, the family had also made efforts to improve their health behavior. 
The family is a component that forms the community unit. If the family is healthy, then the community will be healthy too. In creating a healthy village, the participation of all village communities is very much needed. Through the empowerment of the village community, the sustainability of efforts to build a healthy village will run optimally. The task force team is a group that coordinates community empowerment activities towards a healthy village. The specificity of this healthy village in Tutul Village is that apart from applying the healthy village paradigm in general, an approach is also made so that the community has the ability to independently identify the health status of the family. This is done using the IFHE format. This effort is based on several cases of family health problems in Tutul Village, experiencing delays in making family decisions, so that family members experience delays in handling health. This is according to research by [6]. which states that family duties in implementing clean and healthy living behaviors in Pematang Lalang Village, Subdistrict, with sufficient categories, are associated with the lack of information media. The task force team as coordinators in realizing IFHE-based healthy villages have been given strengthened competence in carrying out tasks in the form of providing health information I, II and III, as well as technical filling in the IFHE format. Based on the results of data analysis, it was found that there was an increase in the understanding of the task force team in receiving the health information provided. Providing health information I with the theme of community health, optimizing nutrition as a prevention of stunting, recognizing cardiovascular disease and death in the perinatal period.

This topic is important to inform, this is in accordance with [7] that to prevent death in the perinatal period, promotive and preventive efforts are needed, such as preventing early marriage, carrying out routine antenatal care, fulfilling nutrition during pregnancy, and so on. The community is also important to recognize the cases of coronary heart disease, according to the research of [8] that most people in Pangandaran Village are overweight (47.1\%) and have abdominal circumference with mild excess $(36.8 \%)$ ), did not exercise $(64 \%)$, had normal blood sugar levels (69\%), and high cholesterol levels (74.7\%). It is said that the risk factors for CHD include being overweight, excess abdominal circumference, lack of activity, and hypercholesterolemia. Apart from this, it is also very important for families to know about stunting. In the research of [9], the factors causing stunting in children under five in Lamongan City are lack of nutritional intake, infectious diseases, and parental characteristics. In addition, [10] also revealed in his research that community health nurse assistance increased the knowledge, attitudes and behavior of high-risk pregnant women and had a positive impact on the level of health service utilization.

Based on the description above, it can be said that an optimal understanding of public health, nutrition in preventing stunting, cardiovascular disease disorders and mortality during the perinatal period is very important to build healthy behavior in society. Through the knowledge competencies possessed by the task force team, "Posyandu" representatives and association representatives, it is hoped that it can be passed on to the community in building healthy perceptions and behaviors.

Based on the provision of 2nd health information, the information has been provided with the theme of recognizing chronic diseases, prevention and management, care and prevention of complications during the postpartum period, as well as adolescent reproductive health. This health information is very important to convey because chronic disease requires a healthy lifestyle pattern that is carried out continuously to prevent recurrence. This is in accordance with the research of [11] that sustainable care interventions in the short term can prevent elderly with chronic diseases from undergoing rehospitalization. Furthermore, families also need to prevent the incidence of postpartum complications with healthy behavior during pregnancy, childbirth and the puerperium. Health education can increase the understanding of postpartum mothers in order to make efforts to prevent complications. This is in accordance with the research results of [12] that "Sehati" health education affects the physiological and psychological adaptation of pre-eclampsia postpartum mothers. The importance of adolescent reproductive health is related to the family in order to build family perceptions in assisting adolescents in preparing healthy reproductive functions. According to research by [13], the factors that influence the behavior of improving reproductive health in adolescents are motivation, attitudes, subjective norms, perceptions and behavior.

In connection with the explanation above, it can be said that if people have healthy perceptions and behaviors about maintaining health in chronic disease conditions, this will reduce the possibility of recurrence. In addition, understanding reproductive health during the postpartum period can also prevent 
the incidence of complications during the puerperium such as puerperal infection, considering that infection is still the third cause of maternal death. Adolescent reproductive health is also an important matter of concern for the community, because through healthy reproduction, adolescents can then go through a period of healthy reproduction at the productive age.

Furthermore, in the $3^{\text {rd }}$ health information provision, health information is delivered that discusses the health of children under five, including stimulation of growth and development of children under five and diseases that often occur in children under five. Another thing that was conveyed was about family planning. The importance of family planning information is in accordance with [14] research that internal factors in women in contraceptive use are fear of contraceptive side effects, external factors, namely husband's perceptions and attitudes, as well as the family environment and the group adopted. The dominant factors, namely culture and religion, on the implementation of the family planning program. Next, the importance of health information for children under five is supported by research by [15] that there is an effect of nutritional supplements and home visits on children's growth and development, and it is said that early stimulation will have a more effective impact.

Based on the above explanation, it can be explained that the growth and development of toddlers really need stimulation in order to reach the normal stage according to their age. Various diseases that occur in toddlers can be at risk of disrupting their growth and development, therefore people need to know how to properly care for toddlers in a healthy condition. In addition, families and communities are also very important to know about family planning to create a healthy and prosperous family. Good family planning will have an impact on healthy reproduction in the mother, optimal childcare patterns, adequate family economic support, because the family can measure the potential of family resources accurately.

Through the coordination of the implementing team, the family gets the health information on very important topics, to open up the family insights about health. This information relates to problems that occur in groups of all ages, from problems with pregnant women, infants and toddlers, school age children, adolescents, adults, the elderly, environmental health conditions and others. Based on this understanding, the family can have a better understanding in making decisions about health problems.

Efforts to create a healthy village based on IFHE in Tutul Village also require monitoring and evaluation media. Therefore, with the IFHE format, the task force team tries to identify developments in family health status continuously. Based on the use of this IFHE format, the family records health development independently, with the assistance of the task force team during the quarter. In the end, family health status can be concluded through the final scoring of the IFHE format with the meaning of good family health, minimal risk, moderate risk or high risk. The results of this conclusion will be a village data report as well as data that will be followed up by health services. Based on this IFHE format, families are also able to make informed family health decisions, because families can recognize the health needs that are urgently needed at that time.

The healthy behavior that must be applied by the family in building a healthy village cannot be temporary, but must be carried out continuously. Therefore, active support from Village institutions, the task force team and the entire community is very much needed. This is because the health of the village community is the responsibility of all villagers.

Based on this research, the contributions that can be given by researchers are 1) the formation of healthy behavior for the community of Tutul Village by optimizing the potential of the community, 2) the village community has the right perception of family health so that they can make family health decisions quickly and accurately, 4) service health can carry out early detection of changes in family health status, 5) morbidity and mortality rates in the community can be reduced. In connection with the contribution of this research, of course further research is needed that can identify the development of new phenomena and find solutions to problems.

\section{CONCLUSION}

1. The efforts to create a healthy village based on Independent Family Health Evaluation (IFHE) in Tutul Village are carried out by forming a task force team as the coordinator of the activities that will be carried out.

2. To strengthen the competence of the task force team in Tutul Village, health information I, II and III have been provided with the result of a significant increase in understanding of health.

3. The Families in Tutul Village attempt to independently identify family health status 
using the IFHE format, with the hope that the family is able to make conclusions on family health status and is able to make quick and accurate decisions when experiencing health irregularities.

4. There is a change in knowledge, skills and health behavior among families in Tutul Village

\section{REFERENCES}

[1] I. Permata Sakti, "Implementasi Program Gerakan Desa Sehat Dan Cerdas (Gdsc) Di Desa Bulu Kecamatan Balen Kabupaten Bojonegoro (Studi Pada Parameter Sehat Indikator Angka Kematian Ibu Dan Angka Kematian Bayi)," Publika, 2017.

[2] M. . Tualeka, "Mewujudkan Desa Sehat: Upaya Mensejahterakan Masyarakat le.” Media Harapan, Maluku Tengah, p. 4, 2017, [Online]. Available: https://mediaharapan.com/mewujudkandesa-sehatupaya-mensejahterakanmasyarakat/.

[3] Ministry of Health, Buku: Panduan Penggunaan Dana Desa untuk Bidang Kesehatan. Jakarta: Indonesia: Kementerian Kesehatan Republik Indonesia, 2016.

[4] Wordpress, "Profil Desa Tutul." Wordpress, p. 3, 2018, [Online]. Available: https://desatutul.wordpress.com/profildesa/.

[5] Imron, "Info Profil Desa Tutul Menuju Desa Handycraft Wisata Religi." Pemerintah Desa Tutul; Jember-Jawa Timur, Jember; Jawa Timur; Indonesia, p. 3, 2012, [Online]. Available:

http://www.wisatacraftjember.com/2012/07 /info-profil-desa-tutul-menuju-desa.html.

[6] N. Manurung, "Faktor-Faktor Yang Mempengaruhi Keluarga Dalam Penerapan Perilaku Hidup Bersih Dan Sehat Di Desa Pematang Lalang," J. Ilm. Keperawatan Imelda, 2018, doi: 10.31227/osf.io/yqjuu.

[7] A. Asmuji and D. Indriyani, "APLIKASI MODEL EDUKASI POSTNATAL MELALUI PENDEKATAN FAMILY CENTERED MATERNITY CARE (FCMC) SEBAGAI STRATEGI OPTIMALISASI COMPETENT MOTHERING," J. NERS, 2016, doi: 10.20473/jn.v11i12016.17-28.

[8] S. H. Pratiwi, E. A. Sari, and R. Mirwanti, "Faktor Risiko Penyakit Jantung Koroner Pada Masyarakat Pangandaran," $J$.
Keperawatan BSI, 2018.

[9] R. Ismawati, R. D. Soeyonoa, I. F. Romadhoni, and I. Dwijayanti, "Nutrition intake and causative factor of stunting among children aged under-5 years in Lamongan city," Enferm. Clin., 2020, doi: 10.1016/j.enfcli.2019.10.043.

[10] A. Melani Astari, Y. Rustina, H. Pratomo, and S. B. Prasetyo, "Improving the utilization of health services among highrisk pregnant women through community health nurse assistance," Enferm. Clin., 2018, doi: 10.1016/S1130-8621(18)300718.

[11] G. Facchinetti et al., "Continuity of care interventions for preventing hospital readmission of older people with chronic diseases: A meta-analysis," International Journal of Nursing Studies. 2020, doi: 10.1016/j.ijnurstu.2019.103396.

[12] E. Ekawati, S. Setyowati, and T. Budiati, "'Sehati' health education to improve physical and psychological adaptation of the postpartum women having pre-eclampsia," Enferm. Clin., 2019, doi: 10.1016/j.enfcli.2019.04.054.

[13] M. Je, H. O. Ju, and J. Lee, "Factors affecting reproductive health promotion behavior among late-adolescent girls in South Korea: A cross-sectional descriptive study," Child. Youth Serv. Rev., 2020, doi: 10.1016/j.childyouth.2020.105347.

[14] T. Bahfiarti, "A case study of psychosocial challenges in the implementation of Family Planning health in the patriarchal society of West Sulawesi," Enferm. Clin., 2020, doi: 10.1016/j.enfcli.2019.07.101.

[15] E. Galasso, A. M. Weber, C. P. Stewart, L. Ratsifandrihamanana, and L. C. H. Fernald, "Effects of nutritional supplementation and home visiting on growth and development in young children in Madagascar: a clusterrandomised controlled trial," Lancet Glob. Heal., 2019, doi: 10.1016/S2214109X(19)30317-1. 